Narrative Irony

in the Contemporary

Spanish-American Novel

Jonathan Tittler

CORNELL UNIVERSITY PRESS

Ithaca and London 
Narrative Irony

in the Contemporary

Spanish-American Novel 
Digitized by the Internet Archive in 2017 with funding from Kahle/Austin Foundation 
THIS BOOK HAS BEEN PUBLISHED WITH THE AID OF A GRANT FROM THE HULL MEMORIAL PUBLICATION FUND OF CORNELL UNIVERSITY.

Copyright (C) 1984 by Cornell University Press

All rights reserved. Except for brief quotations in a review, this book, or parts thereof, must not be reproduced in any form without permission in writing from the publisher. For information address Cornell University Press, 124 Roberts Place, Ithaca, New York 14850.

First published 1984 by Cornell University Press.

Published in the United Kingdom by Cornell University Press Ltd., London.

International Standard Book Number 0-8014-1574-8

Library of Congress Catalog Card Number 83-21074

Printed in the United States of America

Librarians: Library of Congress cataloging information appears on the last page of the book.

The paper in this book is acid-free and meets the guidelines for permanence and durability of the Committee on Production Guidelines for Book Longevity of the Council on Library Resources. 


\section{FOR SUE,}

who shares in all my

joys and uncertainties 
